\title{
Erratum to: The impact of Carpobrotus cfr. acinaciformis (L.) L. Bolus on soil nutrients, microbial communities structure and native plant communities in Mediterranean ecosystems
}

\section{Emilio Badalamenti • Luciano Gristina • \\ Vito Armando Laudicina • Agata Novara • \\ Salvatore Pasta • Tommaso La Mantia}

Published online: 3 November 2016

(C) Springer International Publishing Switzerland 2016

\section{Erratum to: Plant and Soil}

DOI: 10.1007/s11104-016-2924-z

This paper was unfortunately published with error. The given names of the authors have been reversed with the surnames and vice versa, therefore the citation in the external links are incorrect. However, it has been addressed and is not anymore present in the published copies of the article.

The online version of the original article can be found at http:// dx.doi.org/10.1007/s11104-016-2924-z.

E. Badalamenti · L. Gristina · V. A. Laudicina · A. Novara • S. Pasta $\cdot$ T. La Mantia $(\bowtie)$

Agricultural and Forest Sciences Department, University of Palermo, Viale delle Scienze Ed. 4, 90128 Palermo, Italy e-mail: tommaso.lamantia@unipa.it 